\title{
Vocabulary Forgetting, L1 \& L2 Memory Representations and Years of English Disuse: Investigating the Possible Relations
}

\author{
Reza AbBasian and Yaser Khajavi \\ Islamic Azad University, Izeh Branch, Iran
}

Received: 20 June 2010 / Accepted: 19 August 2010

ISSN: 1697-7467

\begin{abstract}
This article aims to investigate the loss of vocabulary after years of English disuse among Iranian teachers. Specifically, it strives to find the effect of period of English disuse on lexical attrition of graduated teachers, and also the cut-of point for lexical attrition in relation to years of English disuse. In addition, it tries to examine if after years of English disuse, teachers will perform better in Persian to English translation or English to Persian translation. 210 teachers participated in the study. Two translation tasks were employed for eliciting the data. The findings of the study revealed that Iranian teachers forget more than $50 \%$ of their word knowledge after 2 years and $90 \%$ of this knowledge will fade after 8 years. Also, it was found that after years of English disuse, English to Persian translation attrition was less than attrition in Persian to English translation. Some implications would be suggested for decreasing the degree of attrition among Iranian teachers.
\end{abstract}

Keywords: Attrition, language disuse, L1, Iranian teachers, L2.

Olvido del vocabulario, representaciones de la memoria en la L1 y L2 y tiempo sin practicar el inglés: investigación de las posibles relaciones

RESUMEN: Este artículo tiene como objetivo investigar la pérdida de vocabulario después de años de desuso del inglés entre los docentes iranies. En concreto, se esfuerza por encontrar el efecto del periodo de desuso del inglés sobre la disminución natural del léxico en los docentes graduados, y también el punto de inflexión de la pérdida de léxico en relación con los años de desuso del inglés.In addition, it tried to examine if after years of English disuse, students will perform better in Persian to English translation or English to Persian translation. Además, trata de examinar si después de años de desuso del inglés los estudiantes se desenvuelven mejor en la traducción del persa al inglés o del inglés al persa. 210 profesores participaron en el estudio. Two translation tasks were employed for eliciting the data. Dos tareas de traducción se emplearon para recabar la información. The findings of the study revealed that there is a meaningful relationship between vocabulary attrition and years of English disuse. Los resultados del estudio revelaron que los profesores iraníes olvidaron más del cincuenta por ciento de su vocabulario después de dos años y el noventa tras ocho años. Also, it was found that after years of English disuse, English to Persian translation attrition was less than attrition in Persian to English translation. Some implications would be suggested for decreasing the degree of attrition among Iranian teachers. Además, se encontró que después de años de desuso del inglés, la pérdida en la traducción del inglés al persa era 
menor que la del persa al inglés. Se sugieren algunas actuaciones para disminuir el grado de desgaste entre los docentes iraníes.

Palabras clave: pérdida de nivel, falta de uso del lenguaje, L1, profesores iraníes, L2.

\section{INTRODUCTION}

In many countries, a huge amount of money is spent annually for teaching English to students. As a result of these attempts, students gain a degree of proficiency. However, as they graduate from university, their English proficiency starts to fade (Marefat \& Rouhshad, 2007). There are many researches on acquisition of language, but a little has been done on attrition of language. As Hansen et al. (2002) put it, «Whereas the study of language learning has received considerable attention over the past half century, research on the loss of language has evolved more recently in applied linguistics» (p. 654). «Lexical attrition has been characterized in terms of loss of vocabulary, loss of semantic distinctions, and in reduced performance ability» (Sands et al. 2007: 55).

One of the most important domains of language research deals with language loss after some periods of disuse. It is reported that one of the problematic issues of EFL graduated students after some years of English disuse is word loss. In recent years, different studies have been conducted on EFL learners in order to probe vocabulary attrition within different periods of disuse. However, most of these studies studied the subjects for short periods of English disuse (between 2 months to 2 years). Since these studies examine language attrition in short periods, attrition does not have sufficient time to influence subjects, and this decreases the validity of the results. Smith (1996) states that those kinds of language attrition researches done in a long period of time could examine numerous structures within larger subject domain. Considering the dearth of longitudinal studies in attrition, it seems beneficial to know the effect of different lengths of period of English disuse by the subjects on lexical attrition and also the cut -of point for lexical attrition in relation to years of English disuse.

\section{REVIEW OF THE RELATED LITERATURE}

\subsection{Attrition and years of language disuse}

Bahrick's (1984) long term study on attrition of Spanish was very insightful and informative in that it was conducted in a long period of time even after more than fifty years of disuse. Moreover, the number of subjects was large and varied. He mentioned that the amount of retention after the first few years remained constant. It means most of the attrition takes place within the early period of disuse to L2/FL, and then gradual attrition will occur.

Some studies indicate that attrition is a process at the early stage of language disuse (Weltens \& Morjon, 1993). Others like Van Ginkel \& Van der Linden (1996) believe that forgetting process likely happens after three or four years of disuse. 
Some studies done by Van Ginkel \& Van der Linden (1996) indicate that attrition almost happens three or four years after graduation while other studies maintain that attrition occurs right after English disuse.

Some other researchers believe that there is an early period of relatively stable retention before attrition gradually takes place. Cohen (1989) states that foreign language attrition considerably occurred nine months after intermittent use of the target language; likewise, Weltens et al., (1989) expressed that earliest period of L2 disuse had no considerable effect on attrition. Kuhberg (1992) and Tomiyama (1994) reported that after six months of L2 disuse considerable attrition happens in children (cited in Wang, 2007).

Bahrick (1984) proposed that some of the Spanish knowledge of his subjects were retrieved after fifty years of disuse because they were in «Permastore» state, i.e. they were in a permanent saved condition, and he believed that the information saved in Permastore aided the subjects to do well in Spanish after taking their classes. He also reported that higher proficient learners' knowledge retained more in Permastore.

Also, Van Ginkel \& Van der Linden (1996) explained that the process of attrition almost happens three or four years after graduation. Considering that the most important constituent part of language is lexicon, researchers put emphasis on the most vulnerable aspect of language to attrition, i.e. vocabulary, in order to find the causes and rate of attrition and compensate for the problem in educational setting.

Considering mentioned studies above, there is no distinct, precise conclusion regarding the years of English disuse and attrition. In order to achieve accurate, valid and insightful data, long-term studies should be conducted. As such, it is important to know the effect of interval of disuse, the fluctuation of attrition rate, and also the cut-off point for lexical attrition within different years of English disuse. As Bahrick (1984: 105) maintains,

Knowledge about attrition would yield benefits to teachers and students of foreign languages, because it would lead to understanding how various procedures of acquisition affect the rate of loss, and would ultimately help to establish optimum conditions of rehearsal, so as to minimize the potential for later attrition (cited in Wang, 2007: 7).

The advantage of present study over previous studies is that language attrition has been investigated in one study while comparing different years of English disuse i.e. 2, 4, 5, 6 7, 8 , and 10 years.

\subsection{Attrition and $L 1$ and $L 2$ representation}

Gascoigne (2001) stated six models of bilingual memory representations and added the seventh one. The first one based on correlated model is the Word Association model, it means for each pair of words in translation, there exist just one conceptual representation and two lexical representations, one for L1 word and the other for the L2 word. There is a link between L1 and L2 lexical representations, and another connection between the L1 representation and the conceptual representation; however, no direct link exists between the L2 representation and the conceptual representation. Therefore, the bilingual first translates the L2 word to L1 word and then gains the meaning of the L1 word by using the link between the L1 word and the concept.

Another model is the Concept Mediation model which is similar to Word Association model since two lexical representations share one concept. In this model, there is a direct 
connection between L1 word and the concept and also between L2 word and the concept, but there is no direct connection between L1 and L2 lexical representation. So, the bilingual must first access the concept and the concept has the mediation role between L1 and L2 representations in order to translate one language to the other. (Gascoigne, 2001: 447).

Gascoigne (2001) believed that the memory of L2 beginner learners work out based on the Association model, while the memory of high proficient L2 learners work out according to Concept Mediation model.

It is vivid since the Concept Mediation model allows the bilingual to think in the L2, while in the Word Association model, the bilingual has to translate all L2 information into L1 and then refers to the concept to access the meaning.

Broadly speaking, beginner learners of a foreign language have to translate information into their L1, while proficient learners directly think in L2 since there exist the direct link between the L2 word and the concept, and it takes a short time in comparison to Word Association model.

Furthermore, Gascoigne noted that the integration of the above two mentioned models named Mixed model in that both the L1 and L2 words have a direct link to the same concept, and also there is a direct connection between L1 and L2 words. But this model specifies strong degree of connections between representation of L2 word and L1 word and between the representation of L1 word and concept and weak degree of connection between representation of L1 word and L2 word and between representation of the L2 word and the concept.

Gascoigne (2001) also elaborates on the Coordinate model in which there are separate representations for the L1 and L2 words, and also two separate representations for the L1 and L2 concept. Although the L1 and L2 word representation are connected to one another, there is a rather different meaning of the two corresponding L1 and L2 words. At last, he described the Distributed model in which there is no connection between L1 and L2 words and also there are many «nodes» showing different aspects of the meaning of the words. He noted that some specific nodes would be linked to both L1 and L2 representations, while some other nodes would be linked to only L1 or L2. Like the previous model, there is a little variation in meaning of the two translation pairs, while they share some conceptual representations by having some common nodes. It could not be said that it is because of their common memory representation since the bilingual memory organization has not clearly explored yet.

In a study Schneider et al. (2002) gave participants, in an initial session, three trials of training on French-English vocabulary pairs and then were tested on these pairs. In the second exam with one week interval, they were retested and then retrained on the same pairs. Both English-French and French-English translations were employed. When initial learning involved the more difficult English-French translation direction or no pre-training on French words. Further, when learning involved the more difficult English-French translation direction or mixed pairs, forgetting across the 1-week interval was decreased.

The «revised hierarchical model» of bilingual memory proposed by Kroll and Stewart (1994) asserts that processing from L1 to L2/FL (for instance, translating L1 words into L2) implicates conceptual memory more than processing from L2 to L1 does.(cited in de Groot \& Keizijer, 2000: 5). Present study aims to investigate the representation of L1 and L2 in Iranian teachers' memory through attrition. 


\section{Method}

\subsection{Research questions}

The study strives to answer the following questions:

1. Do different years of English disuse have any significant effect on attrition of learned vocabulary?

2. Do teachers perform better in Persian to English translation or English to Persian after years of English disuse?

\subsection{Setting and Participants}

210 male Persian literature teachers with different years of experience constituted the sample of this study. The participants were from three provinces of Fars, Yasuj and Khoozestan. They were selected from among 1000 Persian literature teachers from above mentioned provinces. Their age ranged between 25 and 35 .

Persian literature teachers were selected for the study because they have the least use of English after graduation and also they had a large number compared with teachers in other disciplines. For the sake of homogeneity, the participants were assigned into seven groups of thirty with 2, 4, 5, 6, 7, 8, and 10 years of English disuse and only those who had scored between 15-17 in the General English course were selected. This information was collected using a questionnaire.

\subsection{Instrument}

Two translation tasks were used. One task had 20 items which students were required to translate them from English to Persian and another from Persian to English. The items were selected based on their frequency in General English Book of Human Sciences which was a course book for Iranian university students for many years. The rationale behind using translation task for measuring attrition was that firstly, translation task has been used widely in many studies. Secondly, these teachers mostly had learnt the vocabulary through translating the vocabulary into their native language i.e. Persian. In addition, they had been tested also through translation in their examinations i.e. they were required to translate some sentences or vocabulary into Persian. As such, in the study we tested attrition through translation task in order to be consistent with the methodology used for teaching and testing the vocabulary.

\subsection{Procedure}

In the first session, the first task which had 40 items was given to the participants. They were required to translate the words from English to Persian. In the next exam session, the English equivalents of the words were presented to them to be translated to English. Two exam sessions were administered with a one-week interval in order to avoid the effect of learning in first administration i.e. English to Persian translation. 


\section{RESUlts}

In order to answer the questions of the study a number of descriptive and inferential statistics were run. The results are presented in this section.

Research question1. Do different years of English disuse have any significant effect on attrition of learned vocabulary?

Total mean scores of participants are presented in table 1.

Table1. Descriptive statistics for scores of teachers in translation of English words into Persian

\begin{tabular}{|c|c|c|c|c|}
\hline & $\mathrm{N}$ & Mean & $\begin{array}{c}\text { Std. } \\
\text { Deviation }\end{array}$ & Std. Error \\
\hline 2.00 & 30 & 57.1667 & 10.9610 & 2.0012 \\
\hline 4.00 & 30 & 41.0000 & 9.2289 & 1.6850 \\
\hline 5.00 & 30 & 35.6667 & 8.9763 & 1.6388 \\
\hline 6.00 & 30 & 22.6667 & 8.1720 & 1.4920 \\
\hline 7.00 & 30 & 17.5000 & 7.5144 & 1.3719 \\
\hline 8.00 & 30 & 10.6667 & 6.6609 & 1.2161 \\
\hline 10.00 & 30 & 6.5000 & 5.8942 & 1.0761 \\
\hline Total & 210 & 27.3095 & 18.7472 & 1.2937 \\
\hline
\end{tabular}

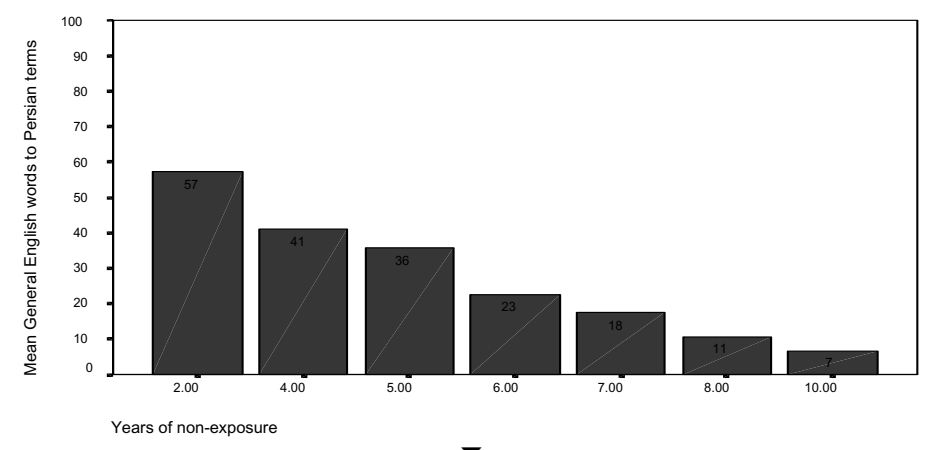

Figure 1. Correct responses of translation of English words into Persian.

The mean scores of group one with 2 years of English disuse shows that participants could not answer almost 50 percents of the words. In addition, group seven with 10 years of English disuse lose almost $94 \%$ percent of their general lexicons. Broadly speaking, the mean scores decrease as the years of English disuse increase, and the standard deviation comes down as the years of English disuse increase. It means the homogeneity of scores increase in long time English disuse. Figure 1 also indicates the decrease of scores as the years of English disuse increase. It also shows the shape and slope of this decrease.

As the results of ANOVA shows between group differences is significant at $F=141.68$, $\mathrm{p}=.000$. This shows that there are significant differences between groups. 
Table 2. Results of ANOVA on translation of English words into Persian.

\begin{tabular}{|c|c|c|c|c|c|}
\hline & $\begin{array}{c}\text { Sum of } \\
\text { Squares }\end{array}$ & DF & $\begin{array}{c}\text { Mean } \\
\text { Square }\end{array}$ & F & Sig. \\
\hline $\begin{array}{c}\text { Between } \\
\text { Groups }\end{array}$ & 59295.714 & 6 & 9882.619 & 141.687 & .000 \\
\hline $\begin{array}{c}\text { Within } \\
\text { Groups }\end{array}$ & 14159.167 & 203 & 69.750 & & \\
\hline Total & 73454.881 & 209 & & & \\
\hline
\end{tabular}

Table 3. Results of Scheffe test on translation of English words into Persian.

\begin{tabular}{|c|c|c|c|c|}
\hline $\begin{array}{l}\text { Years of } \\
\text { English } \\
\text { disuse }\end{array}$ & $\begin{array}{c}\text { Years of } \\
\text { English } \\
\text { disuse }\end{array}$ & $\begin{array}{c}\text { Mean } \\
\text { Difference } \\
(\mathrm{I}-\mathrm{J})\end{array}$ & Std. Error & Sig. \\
\hline \multirow[t]{6}{*}{2.00} & 4.00 & $16.1667^{*}$ & 2.1564 & .000 \\
\hline & 5.00 & $21.5000^{*}$ & 2.1564 & .000 \\
\hline & 6.00 & $34.5000 *$ & 2.1564 & .000 \\
\hline & 7.00 & $39.6667^{*}$ & 2.1564 & .000 \\
\hline & 8.00 & $46.5000^{*}$ & 2.1564 & .000 \\
\hline & 10.00 & $50.6667^{*}$ & 2.1564 & .000 \\
\hline \multirow[t]{6}{*}{4.00} & 2.00 & $-16.1667 *$ & 2.1564 & .000 \\
\hline & 5.00 & 5.3333 & 2.1564 & .414 \\
\hline & 6.00 & 18.3333* & 2.1564 & .000 \\
\hline & 7.00 & $23.5000^{*}$ & 2.1564 & .000 \\
\hline & 8.00 & $30.3333^{*}$ & 2.1564 & .000 \\
\hline & 10.00 & $34.5000^{*}$ & 2.1564 & .000 \\
\hline \multirow[t]{6}{*}{5.00} & 2.00 & $-21.5000 *$ & 2.1564 & .000 \\
\hline & 4.00 & -5.3333 & 2.1564 & .414 \\
\hline & 6.00 & $13.0000^{*}$ & 2.1564 & .000 \\
\hline & 7.00 & $18.1667^{*}$ & 2.1564 & .000 \\
\hline & 8.00 & $25.0000^{*}$ & 2.1564 & .000 \\
\hline & 10.00 & $29.1667^{*}$ & 2.1564 & .000 \\
\hline \multirow[t]{6}{*}{6.00} & 2.00 & $-34.5000 *$ & 2.1564 & .000 \\
\hline & 4.00 & $-18.3333^{*}$ & 2.1564 & .000 \\
\hline & 5.00 & $-13.0000^{*}$ & 2.1564 & .000 \\
\hline & 7.00 & 5.1667 & 2.1564 & .456 \\
\hline & 8.00 & $12.0000 *$ & 2.1564 & .000 \\
\hline & 10.00 & $16.1667^{*}$ & 2.1564 & .000 \\
\hline \multirow[t]{6}{*}{7.00} & 2.00 & $-39.6667 *$ & 2.1564 & .000 \\
\hline & 4.00 & $-23.5000 *$ & 2.1564 & .000 \\
\hline & 5.00 & $-18.1667^{*}$ & 2.1564 & .000 \\
\hline & 6.00 & -5.1667 & 2.1564 & .456 \\
\hline & 8.00 & 6.8333 & 2.1564 & .129 \\
\hline & 10.00 & $11.0000^{*}$ & 2.1564 & .000 \\
\hline
\end{tabular}


Table 3. Results of Scheffe test on translation of English words into Persian. (Cont.)

\begin{tabular}{|c|c|c|c|c|}
\hline $\begin{array}{c}\text { Years of } \\
\text { English } \\
\text { disuse }\end{array}$ & $\begin{array}{c}\text { Years of } \\
\text { English } \\
\text { disuse }\end{array}$ & $\begin{array}{c}\text { Mean } \\
\text { Difference } \\
\text { (I-J) }\end{array}$ & Std. Error & Sig. \\
\hline \multirow{8}{*}{8.00} & 2.00 & $-46.5000^{*}$ & 2.1564 & .000 \\
\cline { 2 - 5 } & 4.00 & $-30.3333^{*}$ & 2.1564 & .000 \\
\cline { 2 - 5 } & 5.00 & $-25.0000^{*}$ & 2.1564 & .000 \\
\cline { 2 - 5 } & 6.00 & $-12.0000^{*}$ & 2.1564 & .000 \\
\cline { 2 - 5 } & 7.00 & -6.8333 & 2.1564 & .129 \\
\cline { 2 - 5 } & 10.00 & 4.1667 & 2.1564 & .712 \\
\hline \multirow{7}{*}{10.00} & 2.00 & $-50.6667^{*}$ & 2.1564 & .000 \\
\cline { 2 - 5 } & 4.00 & $-34.5000^{*}$ & 2.1564 & .000 \\
\cline { 2 - 5 } & 5.00 & $-29.1667^{*}$ & 2.1564 & .000 \\
\cline { 2 - 5 } & 6.00 & $-16.1667^{*}$ & 2.1564 & .000 \\
\cline { 2 - 5 } & 7.00 & $-11.0000^{*}$ & 2.1564 & .000 \\
\cline { 2 - 5 } & 8.00 & -4.1667 & 2.1564 & .712 \\
\hline
\end{tabular}

In order to investigate where the exact differences are, post hoc Scheffe test was run. The results are presented in table 3. The Scheffe test indicates the increase of mean differences and the static status of standard error of differences when the years of English disuse increase. Table 3 also demonstrates the approximation of scores of each previous level with its subsequent level except for the comparison of 2 years with 4 years of English disuse which is highly heterogeneous, and the level of significance is very similar.

\section{Translation of Persian words into English}

Table 4. The descriptive statistics of the translation of Persian words into English.

\begin{tabular}{|c|c|c|c|c|}
\hline $\begin{array}{c}\text { Years of } \\
\text { English } \\
\text { disuse }\end{array}$ & $\mathrm{N}$ & Mean & $\begin{array}{c}\text { Std. } \\
\text { Deviation }\end{array}$ & Std. Error \\
\hline 2.00 & 30 & 33.1667 & 10.4620 & 1.9101 \\
\hline 4.00 & 30 & 27.8333 & 8.5786 & 1.5662 \\
\hline 5.00 & 30 & 24.0000 & 7.4741 & 1.3646 \\
\hline 6.00 & 30 & 12.3333 & 6.3968 & 1.1679 \\
\hline 7.00 & 30 & 8.6667 & 6.6868 & 1.2208 \\
\hline 8.00 & 30 & 3.5000 & 3.7486 & .6844 \\
\hline 10.00 & 30 & 2.1667 & 3.1303 & .5715 \\
\hline Total & 210 & 15.9524 & 13.3967 & .9245 \\
\hline
\end{tabular}

Table 4 shows the mean and standard deviations of participants' scores in the translation of Persian words into English. In this section of the study, the scores highly decrease to the extent that the mean score of group one with 2 years of English disuse is 15 times more than 
group seven with 10 Years of English disuse; specially, the difference between mean scores of group three with 5 years of English disuse and group four with 6 years of English disuse are extremely high i.e. nearly double time. Table 4 demonstrates that the standard deviation also decreases smoothly up to 7 years non-exposure; and then, suddenly changes into half size for 8 years of English disuse. Standard Error of measurement also has the same movement as the standard. deviation when the years of English disuse increase. The interval with $95 \%$ confidence severely decreases in 8 and 10 years of English disuse to English. The bar graph also illustrates these differences.

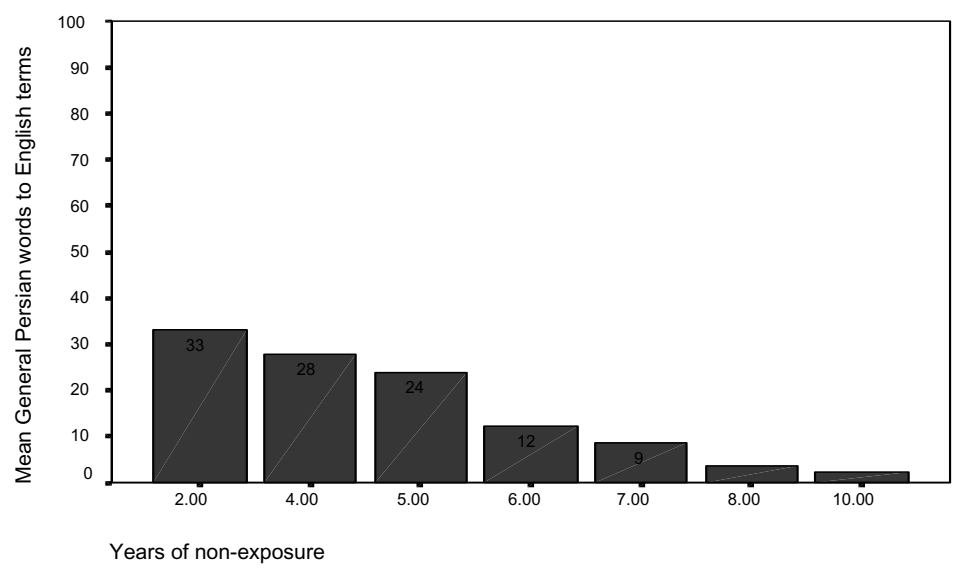

Figure 2. Correct responses of translation of Persian words into English.

Table 5 shows one way the results of one way analysis of variance. The distance between group differences and within group differences is very high, and the probability under $5 \%$ level of significant shows the real differences between different groups with different years of English disuse.

Table 5: Results of One Way ANOVA.

\begin{tabular}{|c|c|c|c|c|c|}
\hline & $\begin{array}{c}\text { Sum of } \\
\text { Squares }\end{array}$ & DF & $\begin{array}{c}\text { Mean } \\
\text { Square }\end{array}$ & F & Sig. \\
\hline $\begin{array}{c}\text { Between } \\
\text { Groups }\end{array}$ & 27406.190 & 6 & 4567.698 & 91.776 & .000 \\
\hline $\begin{array}{c}\text { Within } \\
\text { Groups }\end{array}$ & 10103.333 & 203 & 49.770 & & \\
\hline Total & 37509.524 & 209 & & & \\
\hline
\end{tabular}

The Scheffe test shows the severe mean differences between different groups with different years of English disuse, specially, between 5 and 6 years of English disuse. It is near to 3 times. The mean differences between 6, 7,8 and 10 years of English disuse are less than other 
years of English disuse. The significant level in table 4 shows that the dispersal of scores and approximation of means between individuals with 6,7,8 and 10 years of English disuse are lower than people with 2, 4 and 5 years of English disuse. The Std. Error of differences is fixed. Broadly speaking, there is a relationship between lexical attrition and lexical disuse; it means as the years of English disuse increase, the degree of attrition increases too, but the dispersal of the scores within each year and for every variable is different from one another. The data gathered from the subjects show that there is a gradual difference between groups with two years of English disuse and, the other group with 4 Years of English disuse. The cutoff point for this gradual increase seems to be the eight year as most of the words are attired at this point.

Table 6: Multiple comparisons between years of English disuse and the dependent variable (translation of general Persian words into English).

\begin{tabular}{|c|c|c|c|c|}
\hline $\begin{array}{c}\text { Years } \\
\text { English } \\
\text { disuse }\end{array}$ & $\begin{array}{c}\text { Years of } \\
\text { English } \\
\text { disuse }\end{array}$ & $\begin{array}{c}\text { Mean } \\
\text { Difference } \\
(\mathrm{I}-\mathrm{J})\end{array}$ & Std. Error & Sig. \\
\hline \multirow[t]{6}{*}{2.00} & 4.00 & 5.3333 & 1.8215 & .205 \\
\hline & 5.00 & 9.1667 & 1.8215 & .001 \\
\hline & 6.00 & 20.8333 & 1.8215 & .000 \\
\hline & 7.00 & 24.5000 & 1.8215 & .000 \\
\hline & 8.00 & 29.6667 & 1.8215 & .000 \\
\hline & 10.00 & 31.0000 & 1.8215 & .000 \\
\hline \multirow[t]{6}{*}{4.00} & 2.00 & -5.3333 & 1.8215 & .205 \\
\hline & 5.00 & 3.8333 & 1.8215 & .619 \\
\hline & 6.00 & 15.5000 & 1.8215 & .000 \\
\hline & 7.00 & 19.1667 & 1.8215 & .000 \\
\hline & 8.00 & 24.3333 & 1.8215 & .000 \\
\hline & 10.00 & 25.6667 & 1.8215 & .000 \\
\hline \multirow[t]{6}{*}{5.00} & 2.00 & -9.1667 & 1.8215 & .001 \\
\hline & 4.00 & -3.8333 & 1.8215 & .619 \\
\hline & 6.00 & 11.6667 & 1.8215 & .000 \\
\hline & 7.00 & 15.3333 & 1.8215 & .000 \\
\hline & 8.00 & 20.5000 & 1.8215 & .000 \\
\hline & 10.00 & 21.8333 & 1.8215 & .000 \\
\hline \multirow[t]{6}{*}{6.00} & 2.00 & -20.8333 & 1.8215 & .000 \\
\hline & 4.00 & -15.5000 & 1.8215 & .000 \\
\hline & 5.00 & -11.6667 & 1.8215 & .000 \\
\hline & 7.00 & 3.6667 & 1.8215 & .670 \\
\hline & 8.00 & 8.8333 & 1.8215 & .001 \\
\hline & 10.00 & 10.1667 & 1.8215 & .000 \\
\hline \multirow[t]{4}{*}{7.00} & 2.00 & -24.5000 & 1.8215 & .000 \\
\hline & 4.00 & -19.1667 & 1.8215 & .000 \\
\hline & 5.00 & -15.3333 & 1.8215 & .000 \\
\hline & 6.00 & -3.6667 & 1.8215 & .670 \\
\hline
\end{tabular}


Table 6: Multiple comparisons between years of English disuse and the dependent variable (translation of general Persian words into English). (Cont.)

\begin{tabular}{|c|c|c|c|c|}
\hline $\begin{array}{c}\text { Years } \\
\text { English } \\
\text { disuse }\end{array}$ & $\begin{array}{c}\text { Years of } \\
\text { English } \\
\text { disuse }\end{array}$ & $\begin{array}{c}\text { Mean } \\
\text { Difference } \\
\text { (I-J) }\end{array}$ & Std. Error & Sig. \\
\hline & 8.00 & 20.5000 & 1.8215 & .000 \\
\hline & 10.00 & 21.8333 & 1.8215 & .000 \\
\hline 6.00 & 2.00 & -20.8333 & 1.8215 & .000 \\
\hline & 4.00 & -15.5000 & 1.8215 & .000 \\
\hline & 5.00 & -11.6667 & 1.8215 & .000 \\
\hline & 7.00 & 3.6667 & 1.8215 & .670 \\
\hline & 8.00 & 8.8333 & 1.8215 & .001 \\
\hline & 10.00 & 10.1667 & 1.8215 & .000 \\
\hline 7.00 & 2.00 & -24.5000 & 1.8215 & .000 \\
\hline & 4.00 & -19.1667 & 1.8215 & .000 \\
\hline & 5.00 & -15.3333 & 1.8215 & .000 \\
\hline & 6.00 & -3.6667 & 1.8215 & .670 \\
\hline
\end{tabular}

$R Q$ 2: Do teachers perform better in Persian to English translation or English to Persian after years of disuse?

As shown by tables $1 \& 4$, mean scores of students is English to Persian translation is more than means in Persian to English translation. The difference between mean score of the translation of English to Persian $(\mathrm{M}=27.30, \mathrm{SD}=18.74)$ and Persian to English $(\mathrm{M}=15.95$, $\mathrm{SD}=13.39$ ) is 12. The comparison between attrition of English to Persian and Persian to English translation was conducted through repeated measures ANOVA. Table 7 shows within each group differences for attrition of English to Persian with Persian to English translation. The great differences belong to the comparison between attrition of the group with 2 years of English disuse and group with 4 years of English disuse.

Table 7: Within each group differences for attrition of English to Persian with Persian to English translation

\begin{tabular}{|c|c|c|c|c|c|c|}
\hline Source & $\begin{array}{c}\text { FACTO } \\
\text { R2 }\end{array}$ & $\begin{array}{c}\text { Type III Sum of } \\
\text { Squares }\end{array}$ & df & $\begin{array}{c}\text { Mean } \\
\text { Square }\end{array}$ & F & Sig. \\
\hline FACTOR2 & Linear & 26760.134 & 1 & 26760.134 & $\begin{array}{c}1109.72 \\
6\end{array}$ & .000 \\
\hline $\begin{array}{c}\text { Error(FACTO } \\
\text { R2) }\end{array}$ & Linear & 5039.866 & $\begin{array}{c}20 \\
9\end{array}$ & 24.114 & & \\
\hline
\end{tabular}

As it is shown, $F=1109$, which is significant at .000 . It shows that participants performed significantly in English to Persian translation compared with Persian to English translation. 


\section{Discussion}

The results of this study revealed that there was a close relationship between different years of English disuse and attrition of word knowledge. Additionally, Iranian EFL learners forget more than $50 \%$ of their word knowledge after 2 years and $90 \%$ of this knowledge will fade after 8 years. The results of this study are in conflict with findings from Al-Hazemi (2000) who maintains that the period of English disuse does not seem to have any great impact on the amount of lexical attrition. Decay assumption implies that the frequency and recency of use of the structure (i.e. its continuous activation) is crucial for the maintenance and access of the information in memory. The lack of use of the information results in the dissipation of a «trace» that has been imprinted for a piece of information, represented in the brain (Ecke, 2004: 325). The setting in Iran, in which English language is learnt by the learners, has an important role in the attrition/retention of words. The language attrition of these teachers may be attributed to the fact that they didn't get any English input after graduation due to English language situation in Iran. In ESL contexts, because English language is spoken, learners get input regularly; this helps them rehearse their language knowledge. But in Iran, there is a lack of English language input after graduation which could lead to attrition of learned vocabulary. Some Iranian learners of English forget a large amount of what they learned steadily as no input or adequate exposure to the English language is accessible to them after graduation.

This study demonstrated that after years of disuse, learners will perform better in English to Persian translation than on Persian to English translation. These results are in line with the «revised hierarchical model» of bilingual memory proposed by Kroll and Stewart (1994) which asserts that processing from L1 to L2/FL (for instance, translating L1 words into L2) implicates conceptual memory more than processing from L2 to L1 does.(cited in de Groot \& Keizijer, 2000: 5).

The results of this study have some implications for instructors as well as for officials in educational system. The attrition of word knowledge seems to suggest that there may be some problems in learning English that lead to attrition. So, regular follow up of what the students have learnt seem necessary. This can be done by learners and officials in different ways. Learners can rehearse and practice their English knowledge through reading books, participating in English programs of institutes, surfing the Internet sites which are in English and other activities which help retention of vocabulary. In addition, they can do whatever helps them get English input after graduation. Another responsibility lies in the officials, especially ministry of education, i.e. to encourage the teachers to build up their English language proficiency by assigning some advantages for teachers who take part in English language programs.

In addition, in service English language classes must be included in educational program of teachers in order to enhance their English language proficiency. In these classes, graduation years of teachers should be taken into account, i.e. they should be placed in different groups based on years of English disuse.

\section{Conclusion}

In this study, attrition or word loss of some Iranian teachers was investigated. The results indicated that after 8 years, $90 \%$ of learnt vocabulary knowledge will be forgotten. The period 
of English disuse seems to have a great effect on the amount of lexical attrition. Furthermore, this study demonstrated that after years of English disuse, learners perform better in English to Persian translation than on Persian to English translation. It cannot be claimed that years of English disuse is the only cause of lexical attrition, but at least it is one of the most important determinant factors for lexical attrition. Further research investigating other factors such as motivational or socioeconomic variables affecting attrition and also the study of methodologies used when teaching and learning vocabulary and their effects on attrition could also shed more light on language attrition.

\section{ACKNOWLEDGMent}

The authors are grateful to Professor Daniel Madrid and anonymous referee(s) for their constructive comments on an earlier version of this paper.

\section{REFERENCES}

Al-Hazemi, H. (2000). "Lexical attrition of some Arab speakers of English as a foreign Language: a study of word loss". The Internet TESL Journal. 1, (12). Retrieved from: http //iteslj.org/ Articles/Al-Hazemi-Attrition. accessed 17 May, 2009.

Bahrick, H. P. (1984). "Semantic memory content in premature: Fifty years of memory for Spanish learned in school". Journal of Experimental Psychology, 113: 1-29.

Cohen, A. (1989). "Attrition in the productive lexicon of two Portuguese third language speakers". Studies in Second Language Acquisition.11, 2: 135-150.

de Groot, A. \& Keijzer R. (2000). "What hard to learn is easy to forget: The roles of word concreteness, cognate status, and word frequency in foreign language learning and forgetting". Language Learning, 50, 1: 1-56.

Ecke, P. (2004). "Language attrition and theories of forgetting: A cross-disciplinary review". International Journal of Bilingualism, 8: 321-354.

Gascoigne, C. (2001). "Lexical and conceptual representations in more and less skilled bilinguals: The role of cognates". Foreign language Annals, 34, 5: 446-452.

Hansen, L., Umeda, Y, \& McKinney, M. (2002). "Savings in the Relearning of Second Language Vocabulary The Effects of Time and Proficiency". Language Learning, 52, 4: 653-678.

Kroll, J. F., \& Stewart, E. (1994). "Category interference in translation and picture naming: Evidence for asymmetric connections between bilingual memory representations". Journal of Memory and Language, 33: 149-174.

Kuhberg, H. (1992). "Longitudinal L2-attrition versus L2 acquisition in three Turkish children Empirical findings", Second Language Research, 8, 2: 138-154.

Marefat, H \& Rohshad, A. (2007). "Second language attrition: Are different nouns equally likely to be lost?" Porta Linguarum, 8: 85-98.

Sands, B. \&, Miller, A., \& Brugman, J. (2007). "The Lexicon in Language Attrition: The Case of N|uu. In. Doris L. Payne and Jaime Peña": Selected Proceedings of the $37^{\text {th }}$ Cascadilla Proceedings Project, Somerville, MA, USA. 
Schneider, V., \& Healy, A., \& Bourne, L. (2002)."What Is Learned under Difficult Conditions Is Hard to Forget: Contextual Interference Effects in Foreign Vocabulary Acquisition, Retention, and Transfer". Journal of Memory and Language, 46: 419-440.

Smith, M. T. (1996). Tracking verb usage in adult speakers of Spanish as a second language: An attrition study. M.A. thesis. Brigham Young University, Provo, Utah.

Tomiyama, M. (1994). "Longitudinal second language attrition: Case studies of Japanese returnees". Paper presented at the Annual Meeting of the Teachers of English to Speakers of Other Languages. Baltimore, MD, (ERIC Document).

Van Els, T. (1986). "An overview of European research on language attrition”. In B. Weltens, K. De Bot, \& T. Van Els (Eds.) Language attrition in progress. Dordrecht: Foris.

Van Ginkel, C. I. and Van der Linden, E.H. (1996). "Word associations in foreign language learning and foreign language loss". In K. Sajavaara and C. Fairweather (eds).(pp. 25-33). Approaches to Second Language Acquisition. University of Jyvaskyla.

Wang, S. (2007). Syntactic Attrition in L2 Mandarin Speakers. Unpublished Ph D dissertation. Brigham Young University.

Weltens, B , \& Marjon G. (1993). "Attrition of Vocabulary knowledge”. In: R. schreuder \& B. weltens (Eds). The bilingual lexicon. Amsterdam: Benjamins.

Weltens, B., Van Els, T. J. M., \& Schils, E. (1989). "The long-term retention of French by Dutch students". Studies in Second Language Acquisition, 11: 204-216. 


\section{APPENDIX}

\section{English to Persian Translation}

Please, translate the underlined words.

1.The public bus has a special station.

2.Every lock has a particular key.

3. Saeed Nafisi is a contemporary writer, because he was born in this century.

4.All of the creatures have a special weight.

5.Some happenings are surprising and shock men.

6.To build a house, one should know the principles of building.

7.Black could is the evidence of raining.

8.Last winter, I saw the trace of golf on the snow.

9.I pour the milk in the bowl.

10.Clay is a kind of soil which is used for making vase.

11.The cooked clay objects were called pottery.

12.Swimming in hot weather is enjoyable.

13. Motion and stop are studied in physics.

14.Civilized people have their own culture and language.

15.Water is the combination of Hydrogen and Oxygen.

16.The invention of Electricity changed the men's life.

17.The sculpture of Abolhol is in Egypt.

18.Every kind of verse in any languages has its own harmony.

19. Golestan was written in verse form, but Boostan was written in prose form.

20.Science is too wide to learn.

\section{Persian to English Translation}

Please, translate the underlined words into English.

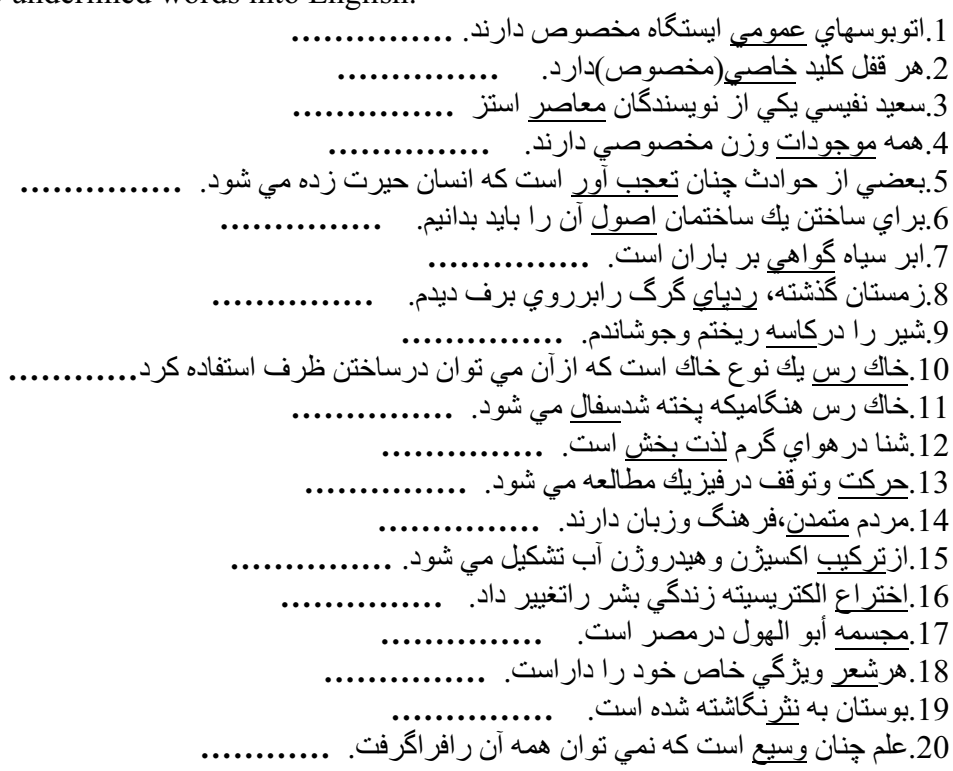

